$\mathbb{T}$ periodica polytechnica

Civil Engineering

$52 / 1(2008) 35,38$

doi: 10.3311/pp.ci.2008-1.05

web: http://www.pp.bme.hu/ci

(c) Periodica Polytechnica 2008

RESEARCH ARTICLE

\section{Historical development of Kosice (Kassa) and its region - geoinformatical analysis}

\author{
András Dénes Ládai
}

Received 2007-12-05

\section{Abstract}

This paper presents an example of historical and social analysis applying geoinformatical methods. The goal is to examine the urbanization process, the development of the city and the countryside and their interactions. Interesting results can be achieved if these procedures are investigated considering the historical periods. What kinds of changes have been caused by the moving of borders (city-, county- and other administrative borders) and by the different political trends? How did these changes take effect on the local people? The techniques of spatial analysis of GIS can provide the answers! The study area was Kosice (Kassa) and its region. Several ethnic groups live (or lived) together here: Slovak, Hungarian, Rusyn and German. Their reactions and movements to historical changes are very interesting to analyse.

Ancient maps of counties of the Hungarian Kingdom and Kosice (Kassa), as well as historical military surveys were used to develop the GIS database. Due to the various data sources, the data quality is very different, but these maps contain the location of townships, their borders and the former land cover and land use. In order to examine the ethnical movements, census' data of different times were used.

Querying this developed GIS the effects of some examined historical periods on this terrain can be traced, e.g. the development of Kosice, and the various movements of ethnic groups.

\section{Keywords}

GIS $\cdot$ urbanization $\cdot$ historical analysis $\cdot$ sociological analysis

\section{András Dénes Ládai}

Department of Photogrammetry and Geoinformatics, BME, Múegyetem rkp. 3. Budapest, H-1521, Hungary

e-mail: alada@mail.bme.hu

\section{Introduction}

The task described in the abstract consists of two separate parts. The first part examines the territorial growth and development of the city of Kosice. The second part deals with a sociological analysis of the city and its surroundings: population growth, changes in the proportion of different ethnic groups and the movement of the borders. The development of the GIS database will be described through examples such as the collection of territorial data, the quality of the data and the results of certain analyses.

\section{The territorial development of the city}

The goal of this part is to examine the changes in land use and land cover within the present territorial boundaries of the city: the development of residential and industrial areas, the drainage of marshlands and river control or in one word: urbanization.

In order to accomplish this task, I used a present town plan and ancient military surveys. Historical military surveys (MS) are generally better suited for this purpose, because they usually cover the city surroundings as well. Table 1 lists the maps used and their features.

The graphic database was developed by vectorizing the scanned files. The pixel size only indicates a theoretical precision. The precision of the absolute position is determined by the fitting and the transformation. The fitting has been done using GPS measurements. The accuracy of the GPS measurement was approximately $30 \mathrm{~m}$. The overall absolute precision is approximately $50 \mathrm{~m}$ by the final estimate. The first military survey contains the earliest data, at the same time this survey is the least precise. Due to its distortion, this map may only give an accurate result within a short distance from the actual control point.

Finally, we shall examine the results. The first figure presents a thematic map of Kosice on the basis of the first military survey. The second figure shows the current situation. The development over two hundred years is striking: the plough-lands and the marshlands have been built-up, the neighbouring towns have merged into the city and housing estates and industrial areas have been created. In order to better understand the development over these years, one could also evaluate the maps from 
Tab. 1.

\begin{tabular}{llllll}
\hline Description & No of section & Date & Scale & Scanning resolution [dpi] & Pixel size [m] \\
\hline Town plan & - & 2000 & $1: 15000$ & 200 & 1.91 \\
\hline Town plan & - & 2000 & $1: 50000$ & 200 & 6.35 \\
I. MS. & Coll. XXIII, Sectio VIII & 1784 & $1: 28800$ & 200 & 3.66 \\
II. MS. & Section 38, Colonne XLI & 1819 & $1: 28800$ & 200 & 3.66 \\
II. MS. & Section 39, Colonne XLI & 1853 & $1: 28800$ & 200 & 3.66 \\
III. MS. & $4466 / 4$ & 1876 & $1: 25000$ & 200 & 3.18 \\
III. MS. & $4566 / 2$ & 1875 & $1: 25000$ & 200 & 3.18 \\
\hline
\end{tabular}

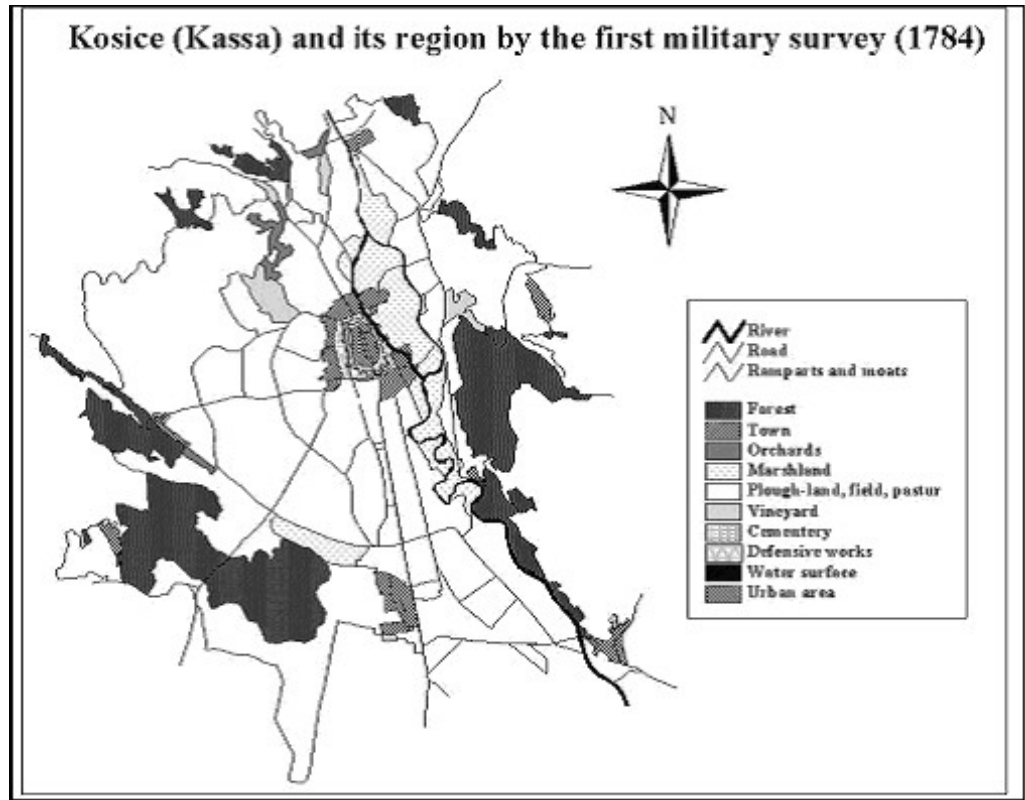

Fig. 1.

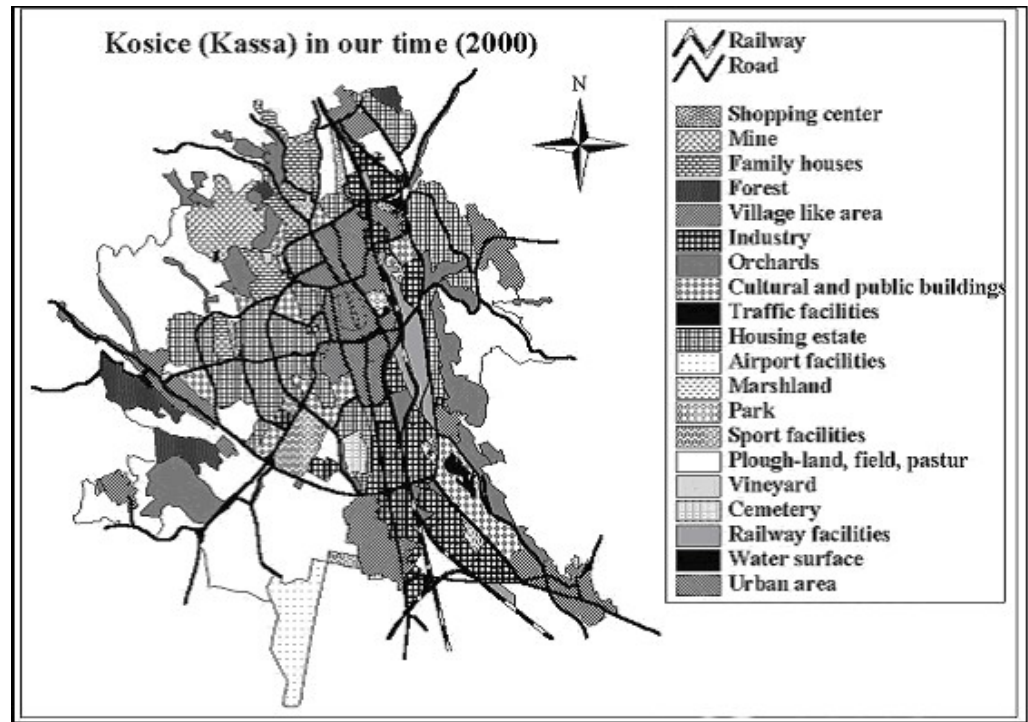

Fig. 2. 


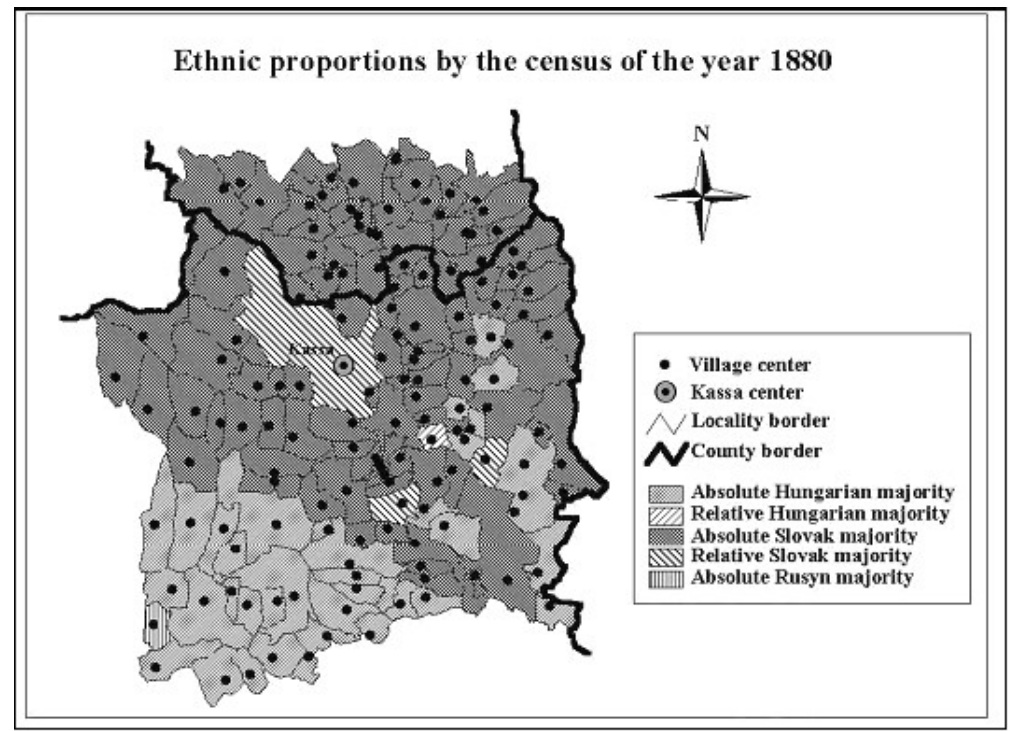

Fig. 3.

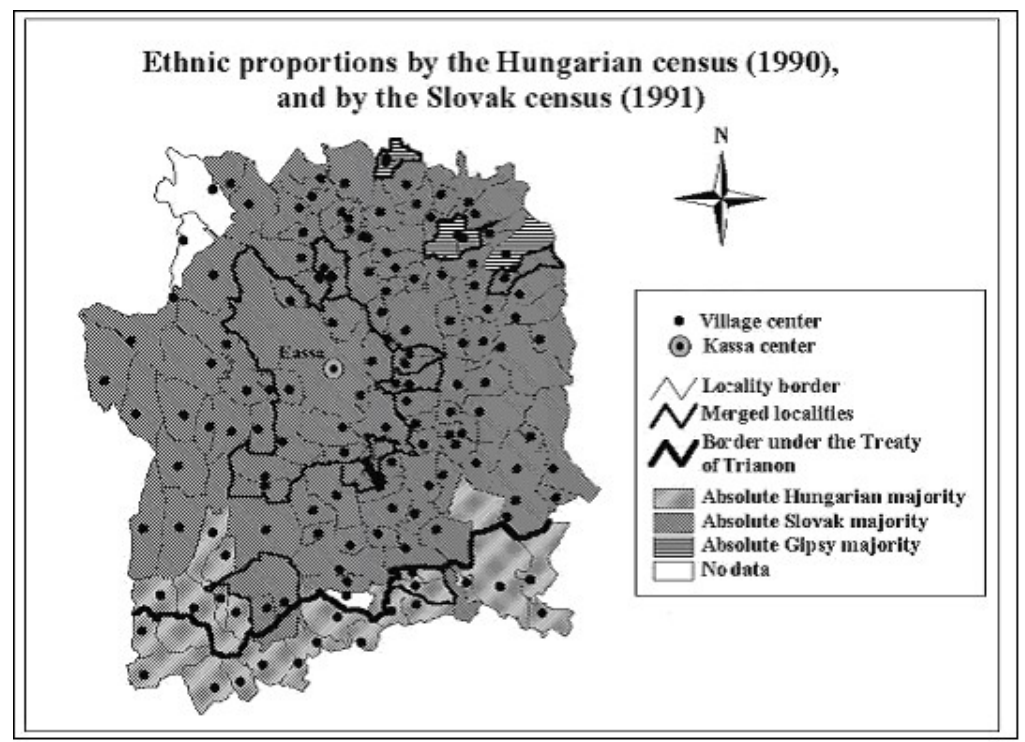

Fig. 4.
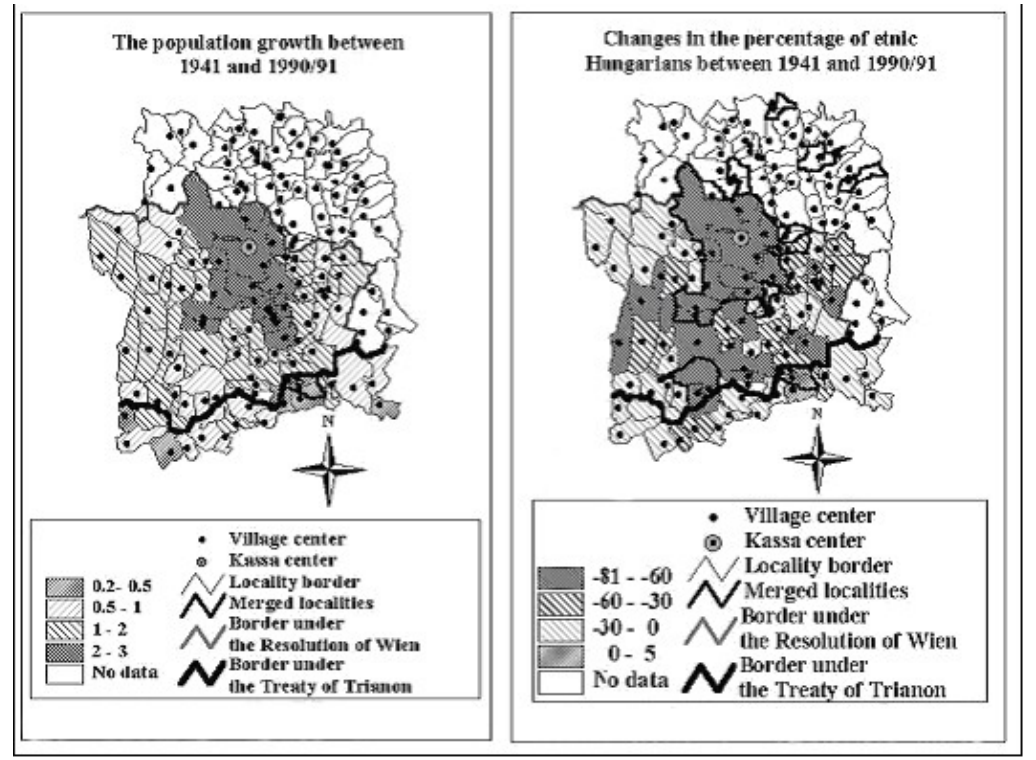

Fig. 5. 
the periods in between.

\section{Sociological analysis}

The everyday life and the development of a city is chiefly determined by its residents. In order to understand the impact of the different historical periods, one must examine the population, its growth and its ethnic composition. Furthermore the development of the countryside around the city must also be taken into account. The goal is to show the interaction between city and countryside over the historical periods.

To develop the graphical database, maps indicating the borders of the settlements were needed. The most suitable ones are contemporary maps of the historical counties of the Hungarian Kingdom. Two counties are concerned: the county of Sáros and the county of Abaúj-Torna. Table 3 lists the corresponding maps.

Tab. 3.

\begin{tabular}{|c|c|c|c|c|c|}
\hline County & $\begin{array}{l}\text { Type of } \\
\text { map }\end{array}$ & Date & Scale & $\begin{array}{l}\text { Scanning } \\
\text { reso- } \\
\text { lution } \\
\text { [dpi] }\end{array}$ & $\begin{array}{l}\text { Pixel } \\
\text { size } \\
{[\mathrm{m}]}\end{array}$ \\
\hline Sáros & $\begin{array}{l}\text { Administrative } \\
\text { and agricul- } \\
\text { tural }\end{array}$ & 1907 & $1: 144000$ & 300 & 12.19 \\
\hline Abaúj- & Transparency & (?) Early & $1: 144000$ & 300 & 12.19 \\
\hline Torna & sketch-plan & $\begin{array}{l}\text { 20th cen- } \\
\text { tury }\end{array}$ & & & \\
\hline
\end{tabular}

The transformation was made in an independent coordinate system, using the coordinate grid of the map. On the basis of some measurements, the relative deviation was approximately 8 $\mathrm{m}$ per $1 \mathrm{~km}$.

The attribute database contains the results of statistical calculations based on census data from the years 1880, 1910, 1941 and 1990-91. The availability of such data makes it possible to examine three distinct periods: the Magyarization between the years 1880 and 1910, the period of changing state borders between the two world wars (1910 and 1941) and the period of Slovakization after the Second World War (1941 and 1990-91).

The evaluation of the results of even a single census is also very informative. Two examples of actual ethnic proportions can be seen in Figs. 3 and 4 .

Fig. 5 examines the period of Slovakization: the population growth and the demographical changes within the Hungarian minority. These two thematic maps indicate the difference between the demographical development of Kosice and its region.

Only a few examples have been presented from the history of Kosice, but it may have been enough to indicate the potential inherent in such complex analyses. They can be considered complex because they cover both the territorial development and the social domain. For further analysis, it is possible to supplement the GIS database by assigning further attributes and more statistical data to reveal further details.

\section{References}

1 Zentai L (ed.), A történelmi Magyarország atlasza és adattára 1914, Talma Kiadó, Pécs, 2001 (Hungarian).

$2 \mathrm{Az}$ 1881. év elején végrehajtott népszámlálás föbb eredményei, Budapest, 1882 (Hungarian). manuscript.

3 A Magyar Szent Korona országainak 1910. évi népszámlálása, A Magyar kir. Központi Statisztikai Hivatal, Budapest, 1912 (Hungarian).

4 Az 1941. Évi népszámlálás, A Központi Statisztikai Hivatal, Budapest, 1947 (Hungarian).

5 A Szlovák Köztársaság településeinek nemzetiségi, vallási adatai 1991, KSH, Budapest, 1996 (Hungarian). 